\title{
Sedimentary facies and model of gentle slope shallow-water braided river delta in the Jurassic Sangonghe Formation, Yanqi Basin, China
}

\author{
Changhai $\mathrm{Li}^{1,2} \cdot$ Lun Zhao ${ }^{1} \cdot$ Guangqing $\mathrm{Yao}^{2}\left(\mathrm{D} \cdot\right.$ Weiqiang $\mathrm{Li}^{1} \cdot \mathrm{Hanbo}^{\mathrm{Liu}}{ }^{2} \cdot$ Yuhan Wang $^{2} \cdot \mathrm{Bing} \mathrm{Wu}^{2} \cdot \mathrm{Yingdi}^{2} \mathrm{Jia}^{2}$
}

Received: 27 April 2018 / Accepted: 13 December 2018 / Published online: 18 December 2018

(c) The Author(s) 2018

\begin{abstract}
The Jurassic Sangonghe Formation of Yanqi basin develops a set of shallow braided river delta deposits, and it is of great significance for the exploration and development of Baolang oilfield to study its sedimentary characteristics. Based on the core data and wire-line log data in the study area with a highly dense well pattern, this work aims to provide the sedimentary features and sedimentary petrofacies distribution of this deposit, and present a sedimentary model for this study area. By analyzing characteristics of lithology-electricity responses, the wire-line log responses of different sedimentary petrofacies in the study area are summarized and the electrofacies recognition template is established. Meanwhile, the planar and profile sedimentary petrofacies distribution is further examined in detail. The results demonstrate that the study area develops coarse clastic sediments, and the sediments are dominated by conglomerate, sandstone, and mudstone, with a characteristic of "rich in sandstone and poor in mudstone". Sedimentary petrofacies are primarily the subaqueous distributary channel facies, with vertically stacked and laterally extensive sandstone bodies. The sedimentary model of shallow-water braided river delta in the study area is characterized by gentle slope, strong current, lacustrine level rising and falling frequently and the thick and wide sandstone bodies.
\end{abstract}

Keywords Baolang oilfield $\cdot$ Shallow-water braided river delta $\cdot$ Gentle slope $\cdot$ Sedimentary characteristics $\cdot$ Sedimentary model

\section{Introduction}

The sedimentary characteristics of shallow-water braided river delta deposits have received great attention over the past several years, with a vast number of reservoirs demonstrated to arise from this kind of depositional environment. Fisk (1954) first defined the term "shallow-water delta", and Donaldson (1974) and Postma (1990) proposed classification systems according to different controlling factors, respectively. Recently, the study of shallow-water delta mainly focuses on formation dynamics, petrofacies architecture, and internal structure (Reading 2013; Lemons and Chan 1999; Plint 2000; Zelilidis and Kontopoulos 2002; Overeem et al. 2003; Leckie et al. 2004; Fielding et al. 2006;

Guangqing Yao

mydreamtomorrow@126.com

1 PetroChina Research Institute of Petroleum Exploration and Development, Beijing 100083, China

2 Faculty of Earth Resources, China University of Geosciences, Wuhan 430074, China
Gani and Bhattacharya 2007; Lee et al. 2015; Howell et al. 2008; Zeng et al. 2015). In China, Gong (1986) first applied the concept of shallow-water delta in the study of Permian deposits in Yu County, Henan Province in the 1980s. Currently, formation conditions, sedimentary models, reservoir characteristics are the main concerns of shallow-water delta research in China (Han et al. 2000; Li et al. 1995; Lou and Cai 1999; He et al. 2001; Zou et al. 2008; Zhu et al. 2008a, b, 2012; Liu et al. 2015; Sun et al. 2016). The reservoirs of shallow-water braided river delta deposit are widely distributed, such as Ordos basin, Bohai bay basin, Songliao basin, Sichuan basin in China (Zhu et al. 2008a, b, 2012; Zou et al. 2008) and Piceance Creek Basin and North Appleby Field in the USA (Bridge and Tye 2000). Most publications, however, focus on the features of the steep slope shallow-water braided river delta deposits and little effort has been made on the gentle slope shallow-water braided river delta deposits.

The Sangonghe Formation in Baobei district of Baolang oilfield provides ideal conditions for a detailed research of gentle slope shallow-water braided river delta. The paucity of study on the sedimentary characteristics and model in 
this area prompts the need for careful efforts to satisfy the acquirement of fine development.

By analyzing the core data and wire-line log data in the study area with a highly dense well pattern, this study discusses the sedimentary characteristics and model and identifies the relationship between its lithology and wire-line log, which can provide a guidance for later field-development and well-completion strategies.

\section{Data sets and methods}

This study is chiefly based on the core data and wire-line $\log$ data. Seven coring wells are attained in the study area, including six conventional cores and one sealed core. About $561.12 \mathrm{~m}$ of cores from these seven wells that distributed evenly in the study area have been observed and described, which can provide the necessary basis for the wire-line log data interpretation.

There are 134 wells totally in the study area, including production wells and injection wells, among which 97 wells run into the objective layer. All wells have wire-line log data which are composed of spontaneous potential log (SP), Gamma ray $\log$ (GR), resistivity log [including deep investigate double lateral resistivity (RD), shallow investigate double lateral resistivity (RS) and microspherically focused logging (RMSL)] and acoustic log (AC). The well-spacing density of the objective layer is up to $0.01 \mathrm{~km}^{2} /$ well, which provides a basis for research on characteristics of sedimentary petrofacies using wire-line log data.

By locating the core, core data and wire-line log data are matched, which contributes to clarify the geological meanings of wire-line log data. Then, electrofacies recognition template is established according to the analyzing outcome. Later, wire-line log data are applied to identify lithology and ascertain the thickness of the sand body for every single well. On the vertical cross-section, the sand body of adjacent wells is correlated and the profile sedimentary petrofacies distribution is analyzed. On the horizontal plane, planar sedimentary petrofacies distribution is displayed based on the electrofacies recognition template. Finally, the sedimentary model of the study area is established according to sedimentary characteristics.

\section{Geological setting}

\section{Basin evolution}

The Yanqi basin is situated in the Southern Tianshan folded belt, which is among the Tarim, Junggar, and Tuha basins. As a Mesozoic and Cenozoic superimposed basin, the basin looks like a NW trend rhombus on morphology, and the length is about $160 \mathrm{~km}$ from nearly east to west, while the width is around $60-90 \mathrm{~km}$ from north to south, over an area of $13,000 \mathrm{~km}^{2}$ (Hu et al. 2006).

The Jurassic palaeogeographic settings of Baobei district were characterized by gentle slope (Wang et al. 2001). The provenance orientation is from the northwest to southeast (Guo et al. 2012). The evolution of Yanqi basin is divided into five stages: (1) triassic foreland basin stage in Yanqi-Kuche area. (2) Jurassic extensive basin stage after the orogenic epoch. (3) Cretaceous uplift and erosion stage caused by compression. (4) Eocene regional subsidence stage caused by breakdown and extension. (5) Quaternary broken intracontinental foreland basin stage.

The Yanqi basin began to receive sediment in the Mesozoic period and was dominated by lacustrine deposits. In the late Triassic, the first lake transgression occurred in the Yanqi basin with the warm and humid paleoclimate, when coal seam deposited in the study area. In the early middle Jurassic, the lake area in the Yanqi basin expanded continuously, depositing the Jurassic Badaowan Formation and Sangonghe Formation, the objective layer of this research. During the period of middle Jurassic Xishanyao Formation, the paleoclimate was humid and attained the maximum flooding surface. Although the paleoclimate turned into dry in the late Jurassic, the basin was characterized by lacustrine sedimentation (Chen 2003). The overall uplift of the late Cretaceous caused the entire Cretaceous strata to be eroded and thus lost. In the Cenozoic era, the Yanqi basin formed a series of anticlines and fractures caused by the Yanshan Orogeny (Yang 2004).

Nowadays, the Yanqi basin is composed of three secondary building units, including Bohu depression, Yanqi uplift and Hejing depression, and the Bohu depression can be subdivided into northern sag, central uplift tectonic belt and southern sag (Fig. 1). The Baobei district is located at the northwest end of the Sumu structural belt, the middle of the northern sag (Du et al. 2012).

\section{Stratigraphy}

The Mesozoic sediments in Yanqi basin covered on the Hercynian fold basement, the subsidence in Yanqi basin began at mid-late Triassic, and ended at the main episode of Yanshan orogeny, the late Jurassic. Namely, the Yanqi basin experienced a complete sedimentary cycle. The episodic tectonic movement formed four third-order sequences, and led to the absence of part stratum (Qiu et al. 2001).

Jurassic strata formed three third-order sequences, including sequence II, sequence III, and sequence IV (Fig. 2). Sequence II developed in the stage of initial subsidence, which belongs to the period of transgression. Sequence III formed in the transitional phase of intensive subsidence to slow subsidence, and occurred the largest lacustrine in the 
Fig. 1 Geographic location and tectonic subdivision of Yanqi basin

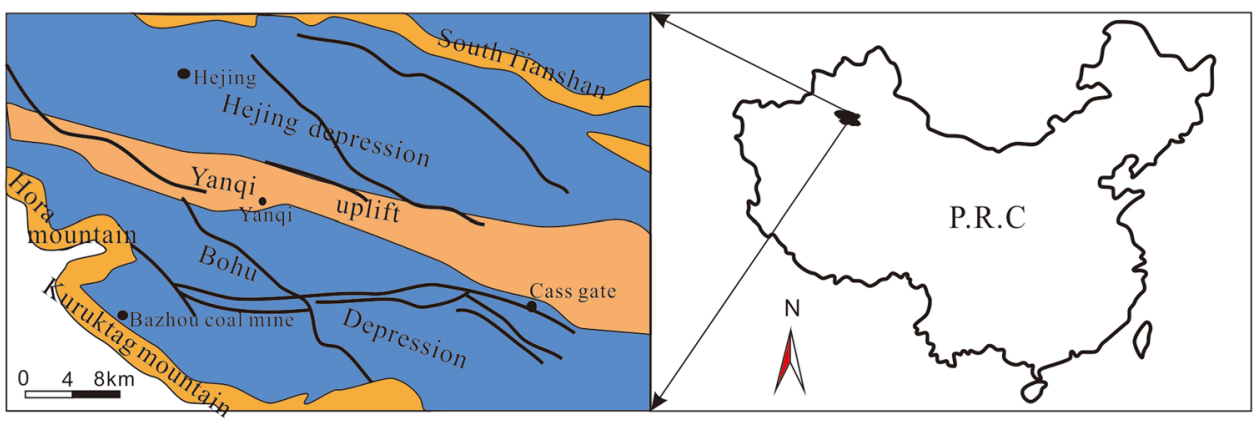

Mesozoic. The development of widely distributed lacustrine mudstone in the upper Jurassic Sangonghe Formation is not only a good regional cap, but also the cap of known oil and gas reservoirs. Sequence IV was the product of basin shrinking, and the transformation of paleoclimate from semiarid to arid conditions which led to the formation of red alluvial deposits.

Jurassic Sangonghe Formation is a part of the sequence III, basically inherits sedimentary framework of Badaowan Formation in the early deposition. Two dustpan-like sags still exist in the south and north, respectively, but the distinction is that the thickness in the north is greater than the south, which demonstrates that depocenter moves to the north. The difference is slightly in the late period of Sangonghe Formation between the south and the north of the basin, and the terrain overall tends to be gentle.

Jurassic Sangonghe Formation represented two depositional system tracts, which are the lowstand system tract and the highstand system tract.

The lowstand system tract: alluvial fan occurs widely in the north of the basin, and extends to the southern part of Baozhong district. The sediments are mainly sandy conglomerate, the thickness of which is more than $20 \mathrm{~m}$, even up to $100 \mathrm{~m}$. The sediments are poorly sorted and sandstone content is generally greater than $60 \%$. Alluvial fan group also emerges along the southern margin of the basin, but on a smaller scale. Braided rivers are widely distributed in the center of the basin, and small shallow-water lakes arise in the late stage. Abundant coarse fragments contribute to the occurrence of a large number of lacustrine deltas and also brings about the outcome that the mudstone thickness is only a few meters.

The highstand system tract: the development of Jurassic lakes enters into heyday in the late period of Jurassic Sangonghe Formation when the basin is dominated by braided rivers, deltas and lakes. Meantime, braided rivers chiefly arise along the northern and southern margin of the basin. The outer edge of the north side develops braided river plain in an arid climate, with thick riverbed glutenite and fuchsia floodplain mudstone. The braided river plain develops in the northern part of Baobei district in a humid climate, which is characterized by overbank swamps and fluvial overflow lacustrine. The lake is distributed in east-west direction, and the area of it is up to $1600 \mathrm{~km}^{2}$.

\section{Sedimentary characteristics}

\section{Petrology features}

The grain size of the sediment, which is the interbedding of sandy conglomerate and mudstone, is coarse (Fig. 3). Both compositional maturity and textural maturity are low, and the composition is mainly lithic (35-60\%), followed by quartz (20-40\%) and feldspar (10-20\%). The sorting is from moderate to poor, with the sorting coefficient of more than 2 , and the roundness is from sub angular to sub rounded, particle-supported.

\section{Sedimentary structures}

Sedimentary structures in the study area point to characteristic of strong hydrodynamic, such as massive bedding, graded bedding, cross-bedding, and parallel bedding. Exceptionally, horizontal bedding reflects the weak hydrodynamic.

1. Massive bedding. It is mainly developed in conglomerate and conglomeratic sandstone, reflecting rapid accumulation of coarse sediment influenced by strong hydrodynamics (Fig. 3a). Alternatively, there is also massive bedding in siltstone and claystone, such as the deposition of mudstone layer in flooding period and rapid accumulation of suspended material of the delta front (Fig. 3b).

2. Graded bedding. It is observed in the fine-to-coarsegrained conglomerate. Large amounts of suspended material begin to deposit with the decrease of mobility and water carrying capacity, indicating the abundant supply of provenance and intermittent flow (Fig. 3c, d).

3. Cross-bedding. Different types of cross-bedding reflect the different transport mechanism of the tractional current, which is the result of bedform migration under distinct hydrodynamic conditions. It is difficult to recognize 


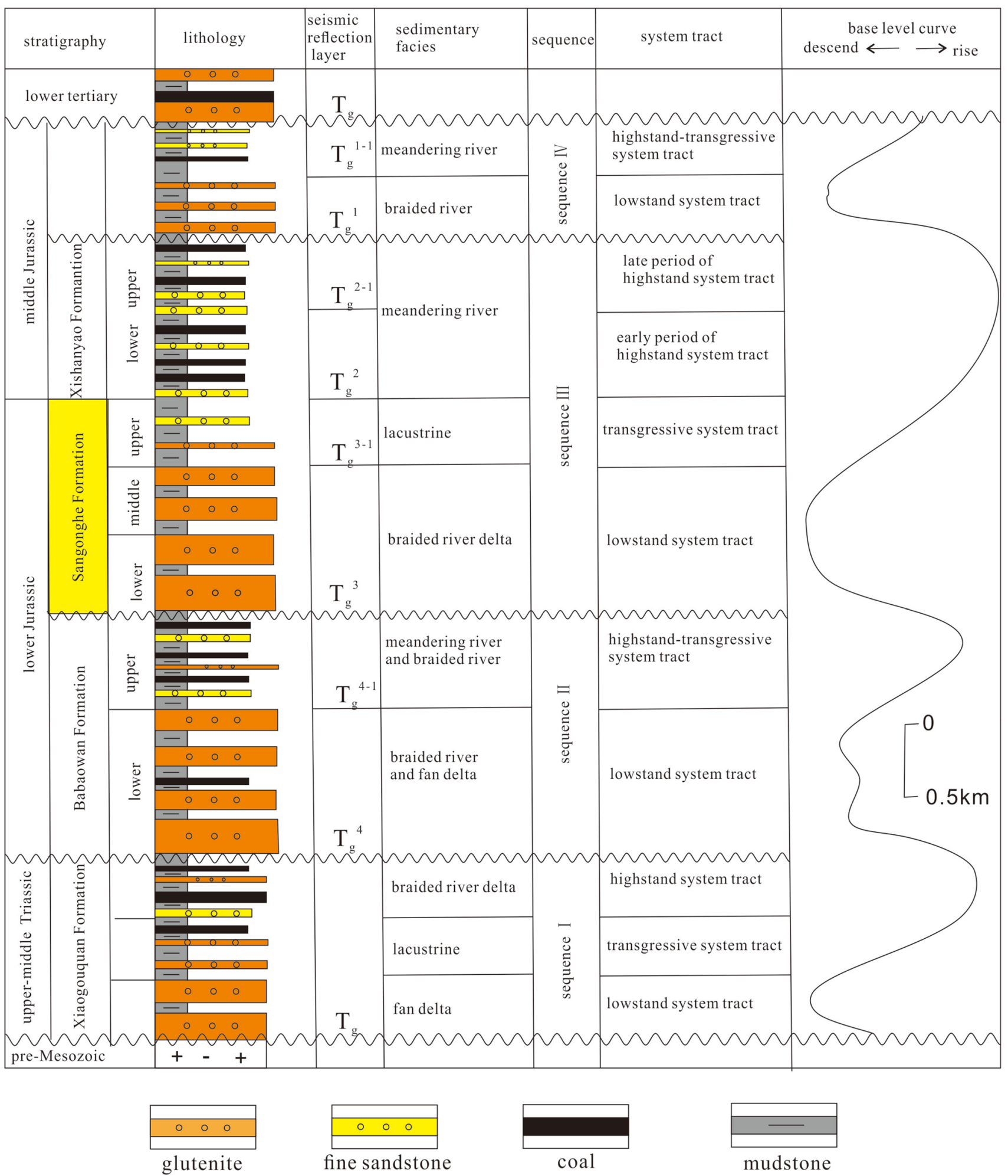

Fig. 2 Mesozoic stratigraphic sequence in the Yanqi basin

the trough cross-bedding because the scale of the core is small. Tabular cross-bedding is more common in gritstone and sandy conglomerate, with more coarsening- upward succession and less fining-upward succession, demonstrating the migration of bedform (Fig. 3e, f).

4. Parallel bedding. On the conditions of the strong hydrodynamic, the sand particles move and roll on the flat 
Fig. 3 Typical sedimentary structures of shallow-water braided delta in Baobei District, Baolang oilfield. a Light grey conglomeratic medium b black carbonaceous shale c light grey medium conglomerate with graded bedding $\mathbf{d}$ light grey gravelly sandstone with parallel bedding e light grey sandy conglomerate with plate cross-bedding f light grey fine sandstone with cross-bedding g light grey fine sandstone with parallel bedding $\mathbf{h}$ light grey medium conglomerate with graded bedding $\mathbf{i}$ dark grey mudstone with coal line sandstone with massive bedding
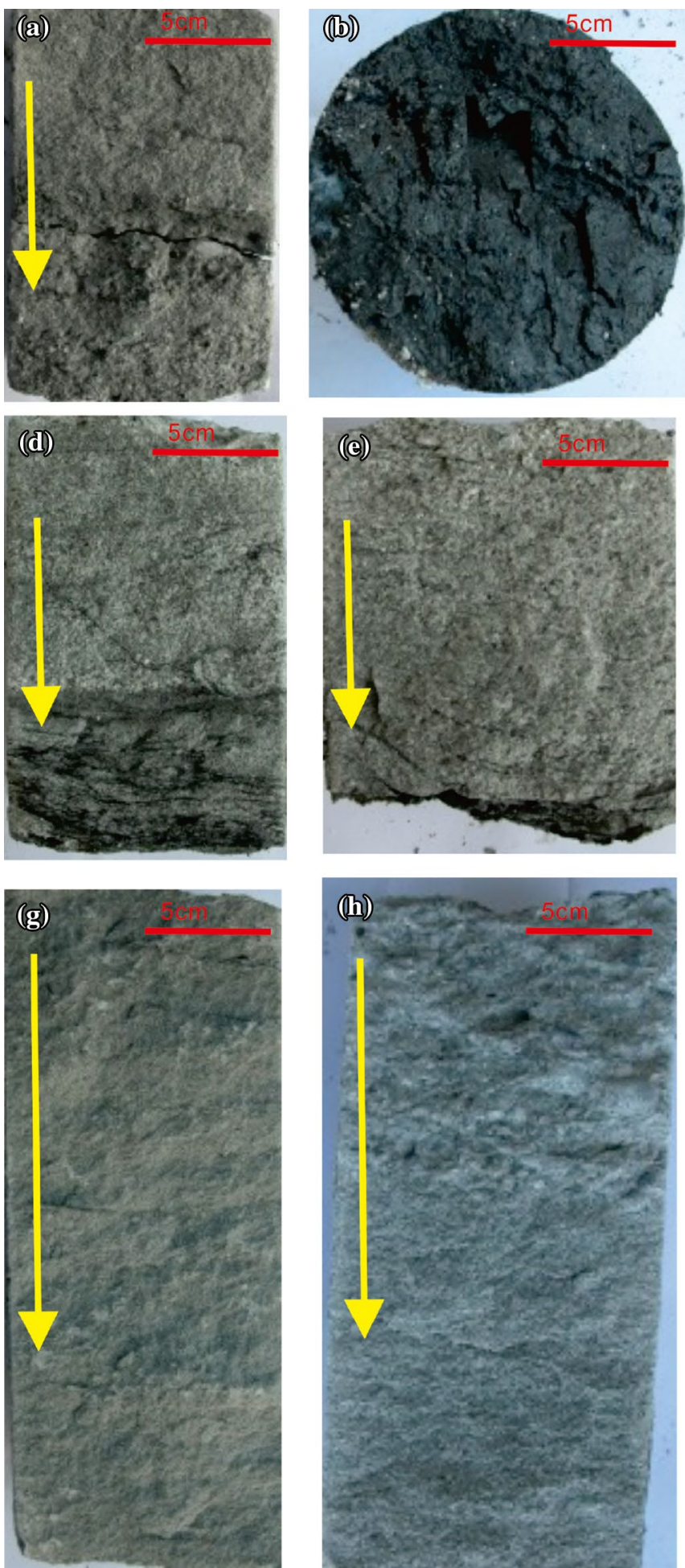

river bed, which gives rise to the separation between coarse-grained sediment and fine-grained sediment. It reflects torrents and upper flow regime (Fig. 3g).

5. Horizontal bedding. Horizontal bedding usually represents a relatively still and lower flow regime. The siltstone and mudstone in the study area develop massive
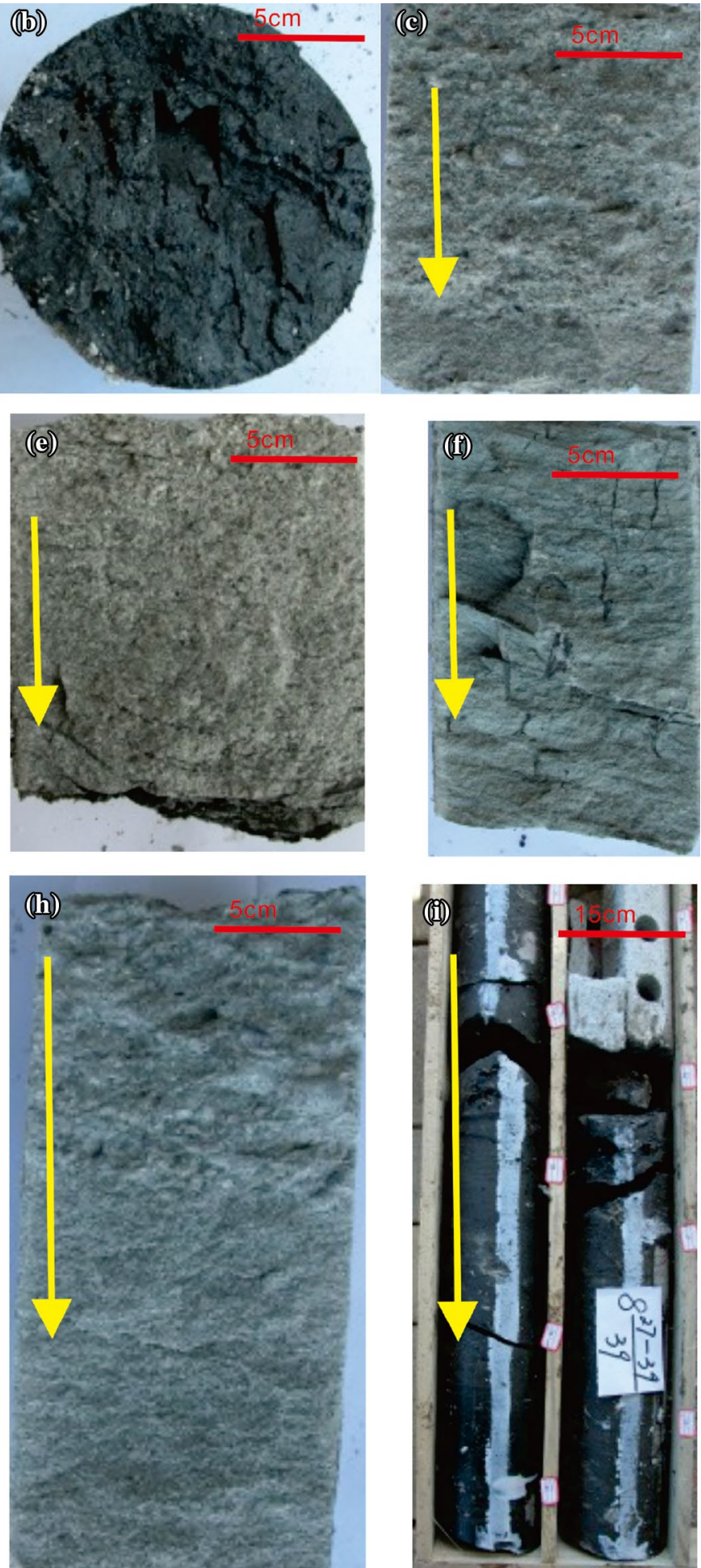

bedding primarily, with horizontal bedding occasionally, which can be seen in the interdistributary bay (Fig. 3h). 


\section{Grain size distribution}

The grain size of sediment depends on transporting medium, transporting mode and sedimentary environment, and grain size analysis is an important method to determine the sedimentary environment (Zhao and Zhu 2001). The probability cumulative curve of the study area is mainly made up of two segments. The figure $\mathrm{C}-\mathrm{M}$ is dominated by $\mathrm{QR}$, followed by PQ and RS, which indicate the characteristics of strong hydrodynamic and short-distance transportation (Fig. 4). According to Zheng's summary (Zheng and Ming 1989), the sedimentary environment is a braided river.

\section{Lithofacies types}

To reflect the changes of the hydrodynamic in the process of deposition and eliminate the uncertainty of the single sedimentary structure, the concept of the lithofacies was introduced (Miall 2006). Lithofacies is the sum of the rock characteristics formed under specific flow regime, which is significant for inferring transporting mode, hydrodynamic condition and sedimentary environment (Chen et al. 2013; Li and Huang 2017).

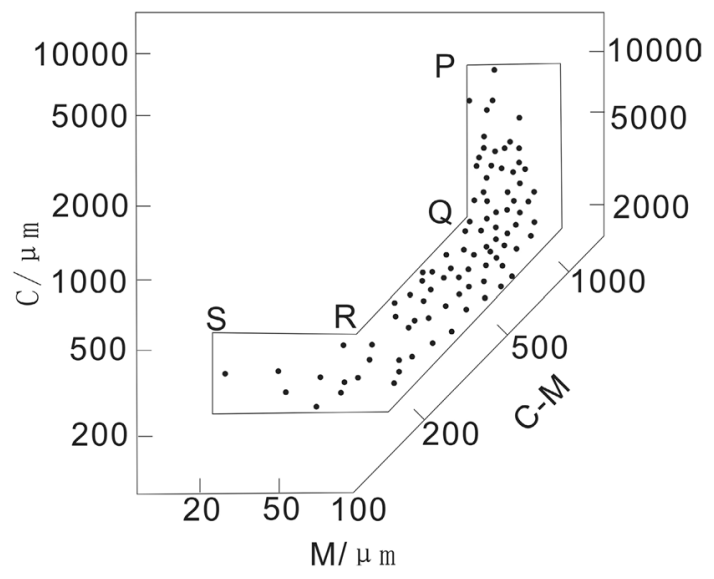

Based on the coring well data of Bao1252, the analysis of the lithology, granularity, sedimentary structure, and configuration relationship is carried out, and eight types of lithofacies are identified (Table 1).

1. LF1: Massive bedding conglomerate facies

With sandstone and conglomerate mixed and high content of conglomerate in lithic, both the sorting and the roundness of LF1 are poor. The LF1 is characterized by high content of matrix and loose cementation, where coal and mud bricks are common to see. Massive bedding is dominated, and imbricated structures occur occasionally. Scoured base is developed at the bottom of LF1. LF1 indicates abrupt high-energy regime.

2. LF2: Large trough cross-bedding sandy conglomerate facies

The sorting and roundness of sandy conglomerate are medium and poor, respectively. Large trough cross-bedding develop in LF2, but it is difficult to identify it in the core for the small scale. Scoured base is developed at the bottom locally. LF2 reflects a strong tractional current in a highenergy environment.

3. LF3: Large tabular cross-bedding sandy conglomerate facies

Both the sorting and roundness of the sandy conglomerate are medium. LF3 develops unclear tabular cross-bedding, which is manifested by the orientation of conglomerate or laminae. LF3 demonstrates tractional current in high-energy environment.

\section{LF4: Graded bedding sandstone facies}

LF4 is dominated by mid-fine grained sandstone, with conglomerate at the bottom. The bottom of LF4 exists

Fig. 4 Figure C-M of sandbody in Baolang oilfield

Table 1 Lithofacies types and genetic interpretation of III Formation in Baobei block, Baolang oilfield

\begin{tabular}{|c|c|c|c|c|c|}
\hline Types & Code & Genetic interpretation & Types & Code & Genetic interpretation \\
\hline $\begin{array}{l}\text { Massive bedding conglomer- } \\
\text { ate facies }\end{array}$ & LF1 & Abrupt high-energy regime & $\begin{array}{l}\text { Parallel bedding sandstone } \\
\text { facies }\end{array}$ & LF5 & Medium-energy tractive current \\
\hline $\begin{array}{l}\text { Large trough cross-bedding } \\
\text { sandy conglomerate facies }\end{array}$ & LF2 & $\begin{array}{l}\text { Tractional current in high- } \\
\text { energy environment }\end{array}$ & $\begin{array}{l}\text { Wave bedding fine sandstone } \\
\text { facies }\end{array}$ & LF6 & $\begin{array}{l}\text { Medium-energy environment } \\
\text { with the affection of wave }\end{array}$ \\
\hline $\begin{array}{l}\text { Large tabular cross-bedding } \\
\text { sandy conglomerate facies }\end{array}$ & LF3 & $\begin{array}{l}\text { Tractional current in high- } \\
\text { energy environment }\end{array}$ & $\begin{array}{l}\text { Mixed bedding sandstone and } \\
\text { mudstone facies }\end{array}$ & LF7 & $\begin{array}{l}\text { Medium-low energy environ- } \\
\text { ment with the affection of } \\
\text { wave }\end{array}$ \\
\hline $\begin{array}{l}\text { Graded bedding sandstone } \\
\text { facies }\end{array}$ & LF4 & $\begin{array}{l}\text { Abrupt gravity current or high } \\
\text { energy environment }\end{array}$ & $\begin{array}{l}\text { Horizontal bedding mudstone } \\
\text { facies }\end{array}$ & LF8 & $\begin{array}{l}\text { Low-energy environment with a } \\
\text { certain depth of water }\end{array}$ \\
\hline
\end{tabular}


scouring surface. LF4 points to an abrupt gravity current or high-energy environment.

\section{LF5: Parallel bedding sandstone facies}

LF5 is mainly composed of fine sandstone, and there exists conglomerate locally. Both the sorting and the roundness are fairly well. LF5 represents medium tractional current.

\section{LF6: Wave bedding fine sandstone facies}

LF6 is dominated by fine sandstone, with minor conglomerate locally. Both the sorting and the roundness are moderate. LF6 indicates medium-energy environment affected by wave.

\section{LF7: Mixed bedding sandstone and mudstone facies}

The lithofacies of LF7 are interbedded layers of fine sandstone and mudstone. The mixed bedding mainly includes wavy, flaser, and lenticular bedding. Bioturbation structure and vertical bur are visible in LF7. LF7 represents medium-low energy environment affected by waves.

\section{LF8: Horizontal bedding mudstone facies}

The color of mudstone is dark grey or black. LF8 develops horizontal bedding and massive bedding locally. It contains animal shell fossil and a small amount of plant stem fossils. LF8 represents low-energy environment with a certain depth of water.

\section{Fossil characteristics}

In the study area, the fossils of plant stem and leaf can be seen, which represent the low-energy regime during the intermittent period of the flood. Bioturbation structure is common, and animal shell fossils can be seen occasionally, which primarily exist between the layers, indicating the sedimentary characteristics of interdistributary bay. The characteristics of these fossils imply the humid climatic conditions suitable for plant growth and the frequent changes of the shallow-water body.

\section{Sedimentary facies characteristics}

\section{Electrofacies recognition template}

According to the rock types, sedimentary structures, grain size characteristics, lithofacies types and palaeontology and other sedimentary facies markers, combined with wire-line log data, it is considered that Sangonghe Formation in Baobei district, Baolang oilfield mainly develops braided river delta front subfacies. Based on the analysis of coring well data of Bao 1252, four types of petrofacies are identified: subaqueous distributary channel, mid-channel bar, channel lateral margin and interdistributary bay (Fig. 5).

Restored to logging curve elements, including amplitude, shape, contact relationship of the top and the bottom, smoothness, and tooth midline, the GR curve of 97 wells in the study area is analyzed. Eleven types of electrofacies are identified, including the funnel-shape, box-shape, bellshape, serrated thick logging curve and near-linear thin logging curve and so on (Fig. 6).

Aided by the data of seven coring wells, the correspondence between the electrofacies and the sedimentary petrofacies is established, and then electrofacies recognition template of III Formation in Baobei District, Baolang Oilfield is summarized.

\section{Sedimentary petrofacies distribution}

To study profile sedimentary petrofacies of Sangonghe Formation in Baobei District, Baolang Oilfield precisely, three longitudinal sections that are parallel to the northeast provenance and three longitudinal sections that are perpendicular to the northeast provenance are selected, respectively. Taking two representative longitudinal sections that are perpendicular to the source as an example (Fig. 7), the vertical sedimentary petrofacies distribution is discussed. According to the morphological characteristics of longitudinal sedimentary petrofacies, the sand bodies are divided into four types: large, medium, small channel sand bodies and thin sand sheet.

The outcomes show that sand bodies thickness of Sanggonghe Formation changes slightly in the perpendicular direction of the provenance. Alternatively, large and medium-sized channel sand bodies account for more than $90 \%$. Transversely, the lateral extent of the sand body is up to $500 \mathrm{~m}$ with good connection. Vertically, sand bodies are stacked, with thick single sand body that is more than $10 \mathrm{~m}$ and thin interlayer. Taking the Layer $\mathrm{III}_{2}{ }^{1+2}$ as an example, the distribution of sandbody thickness is shown in the Fig. 8 . And the range of sandbody thickness is displayed in Fig. 9. The contact relationship between different sand bodies can be summed up as five types, including vertical superposition, vertical tangency type, lateral superposition, lateral tangency type, and vertical separated (Fig. 10).

In the transverse plane, distribution of sedimentary petrofacies on planar is analyzed, which is based on the distribution of sand body thickness and the response characteristics of wire-line log (Figs. 8, 11). It should be noted that the planar sedimentary facies are the overall characteristics of vertically stacked sand bodies in a certain period of time, and the large

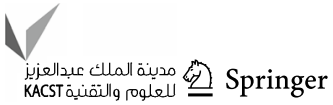




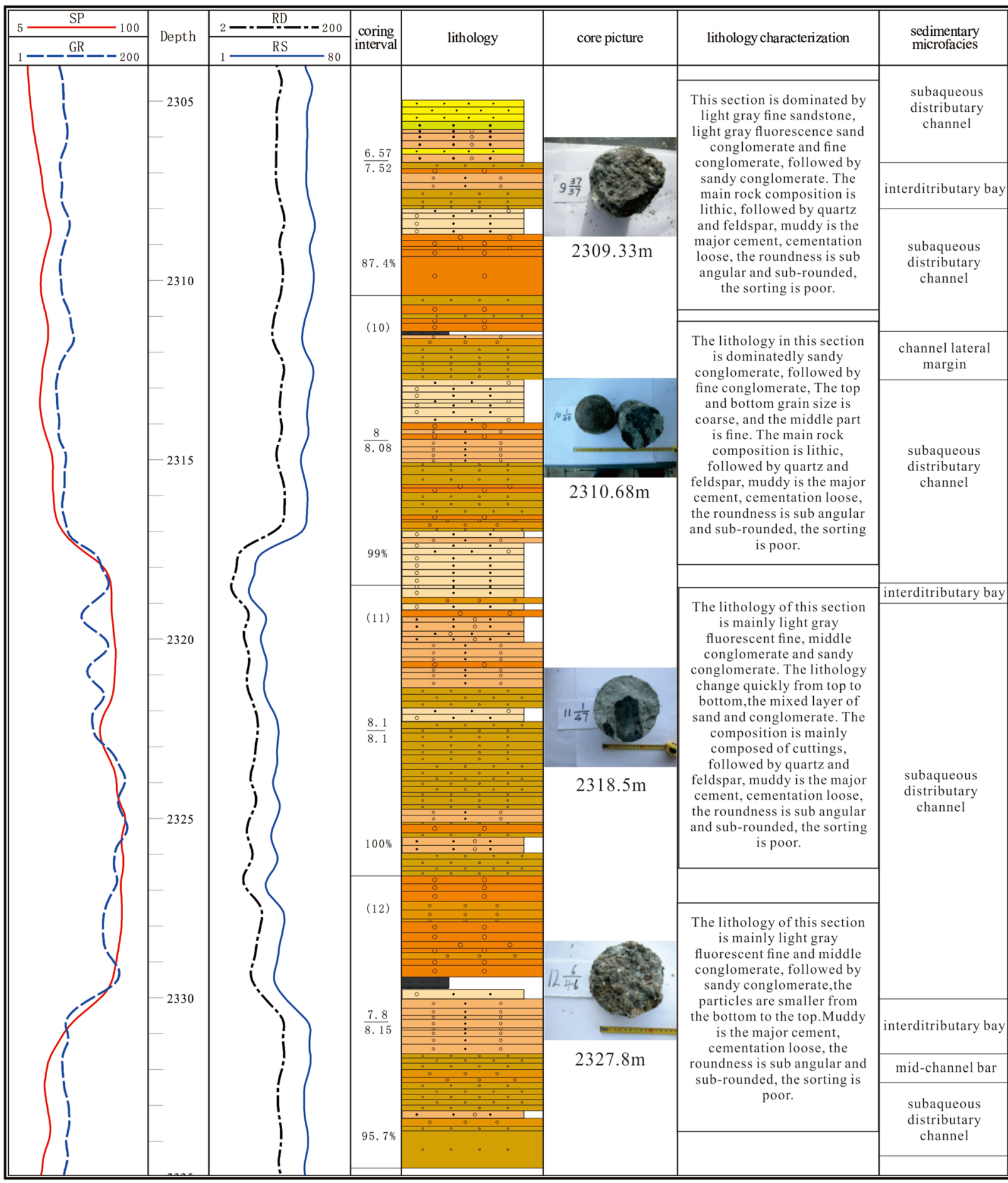

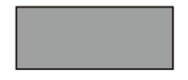

mudstones

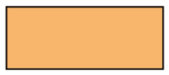

sandy conglomerates fine conglomerates

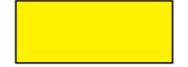

fine sandstones

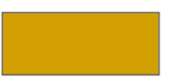

Fig. 5 Synthesis columnar section of core sedimentary petrofacies of well Bao 1252
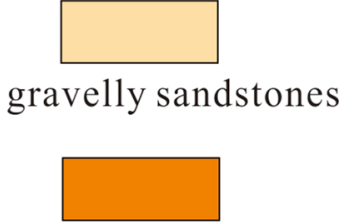

cobble conglomerate

1

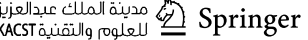


Fig. 6 Electrofacies recognition template

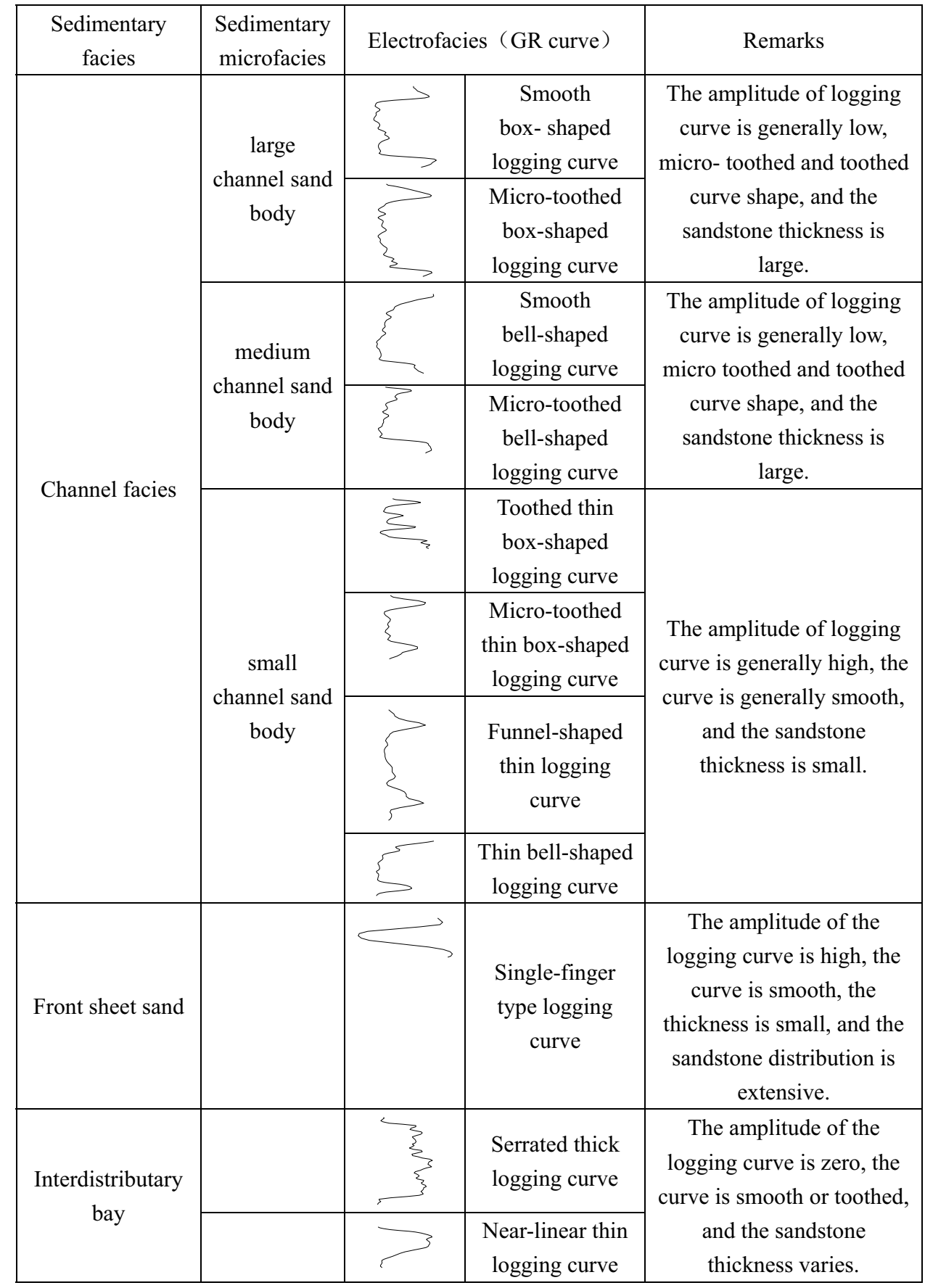

thickness of sandbody that is wide strip or sheet-like actually represents the lateral migration range of sandbody in the certain period of time, namely, the frequency of sedimentary petrofacies turns up, instead of the single sand body actual thickness. The geological significance is that according to the sand body types, cumulative thickness and the occurrence, we can both determine the continuity of sand bodies and the position of the subaqueous distributary channel facies. The results manifest that there are three rivers in the study area, and the subaqueous distributary channel facies is dominated, followed by channel lateral margin, and a large number of mid-channel bars exist. The river features of this study area are exhibited in Table 2.

\section{Sedimentary model}

Based on the geological background, core data and wire-line log data of III oil-bearing interval of Sanggonghe Formation in Baobei district, Baolang oilfield, 


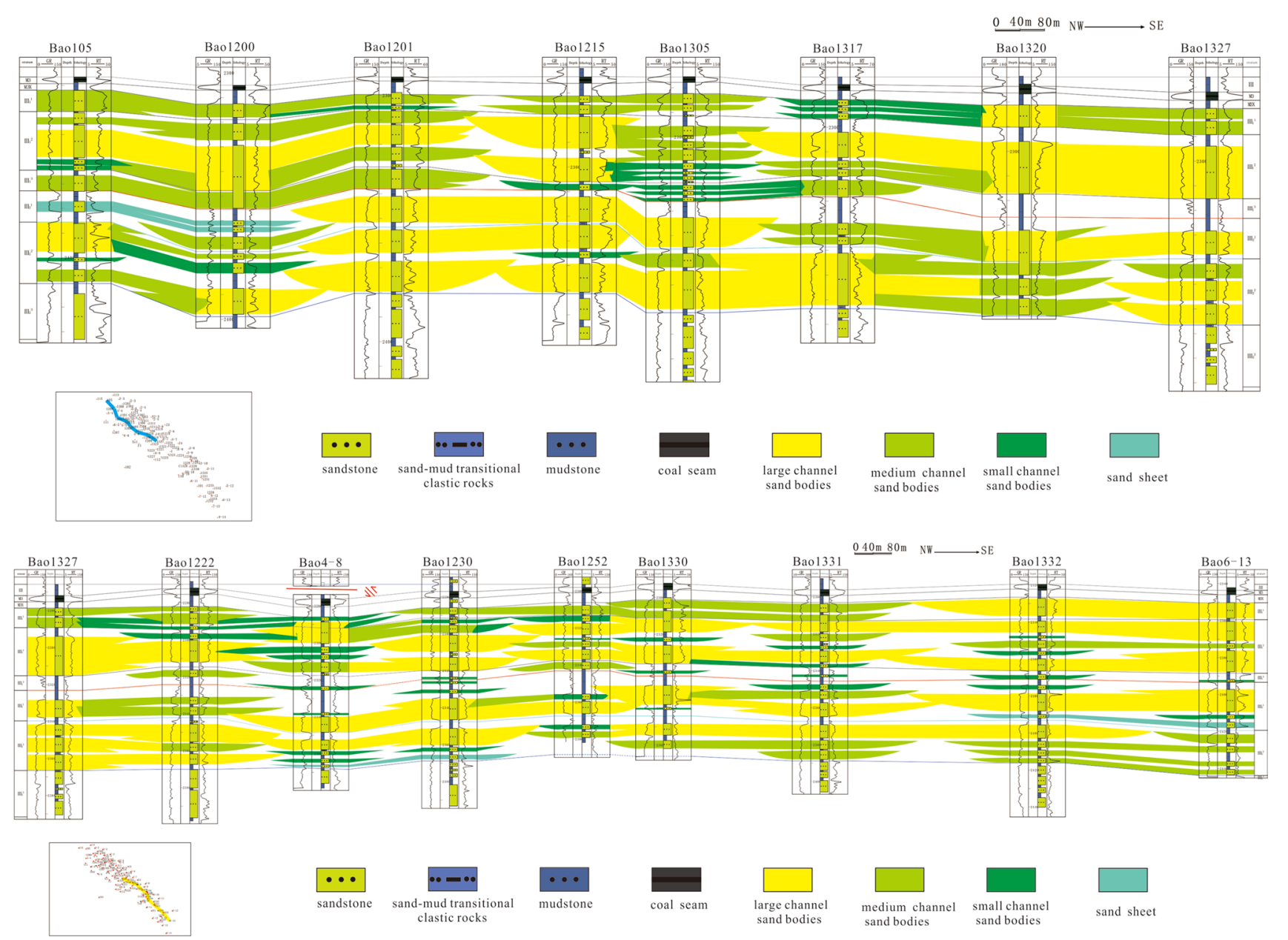

Fig. 7 Vertical section of sedimentary petrofacies of III oil-bearing interval of Sanggonghe Formation in Baobei block, Baolang oilfield

the sedimentary model of the study area are reconstructed (Fig. 12).

In the early period of Jurassic Sangonghe Formation, the sedimentary background is regressive systems tract with a wide lake-basin. The study area lies in the gentle slope of the northern part of Yanqi basin, where the lake area changes greatly in response to the slight variation of a shallow-water body. Periodic precipitation occurs in the study area with the influence of the humid climate, causing frequent fluctuation of the lake level. Furthermore, the steady subsidence of the basin provides adequate accommodation for the deposition, and the clastic materials transported from the northern edge of the basin deposit in the lake continuously.

The process of deposition in the study area can be summarized as follows:

In stage of the lake level declines, both the lake area and the river hydrodynamic force descended gradually, causing the movement of the delta front toward the center of the basin. The river gradually formed a relatively fixed river channel. Accommodation is reduced with the accumulation of sediment, leading to the lateral migration of sandbodies. Thus, the distribution of sandbodies in the study area was continuous. After the river entered the lake, subaqueous distributary channel width suddenly increased significantly due to the flat terrain in the shallow-water. And this was the reason why a large amount of mid-channel bar occurred. In the low water period, the sand body was exposed to air and vegetation grew in the study area, forming the coal sediment in the delta front.

In the flooding period, the fixed channel in the period of low water was submerged by the lake water. The position of the river entering the lake had changed, resulting in formation of new deposition at a new place. The sedimentary area of sand body changed into a deep water environment with the increase of the lake level and began to deposit mudstone, forming the interlayer of the study area.

During the deposition period, the delta front continuously experienced the cycle, "In the low water period, the sandstone deposited, and in the flooding period, the mudstone deposited". Although the length of the dry season 
Fig. 8 Sandbody thickness contour line of Layer $\mathrm{III}_{2}{ }^{1+2}$ in Baobei District, Baolang oilfield

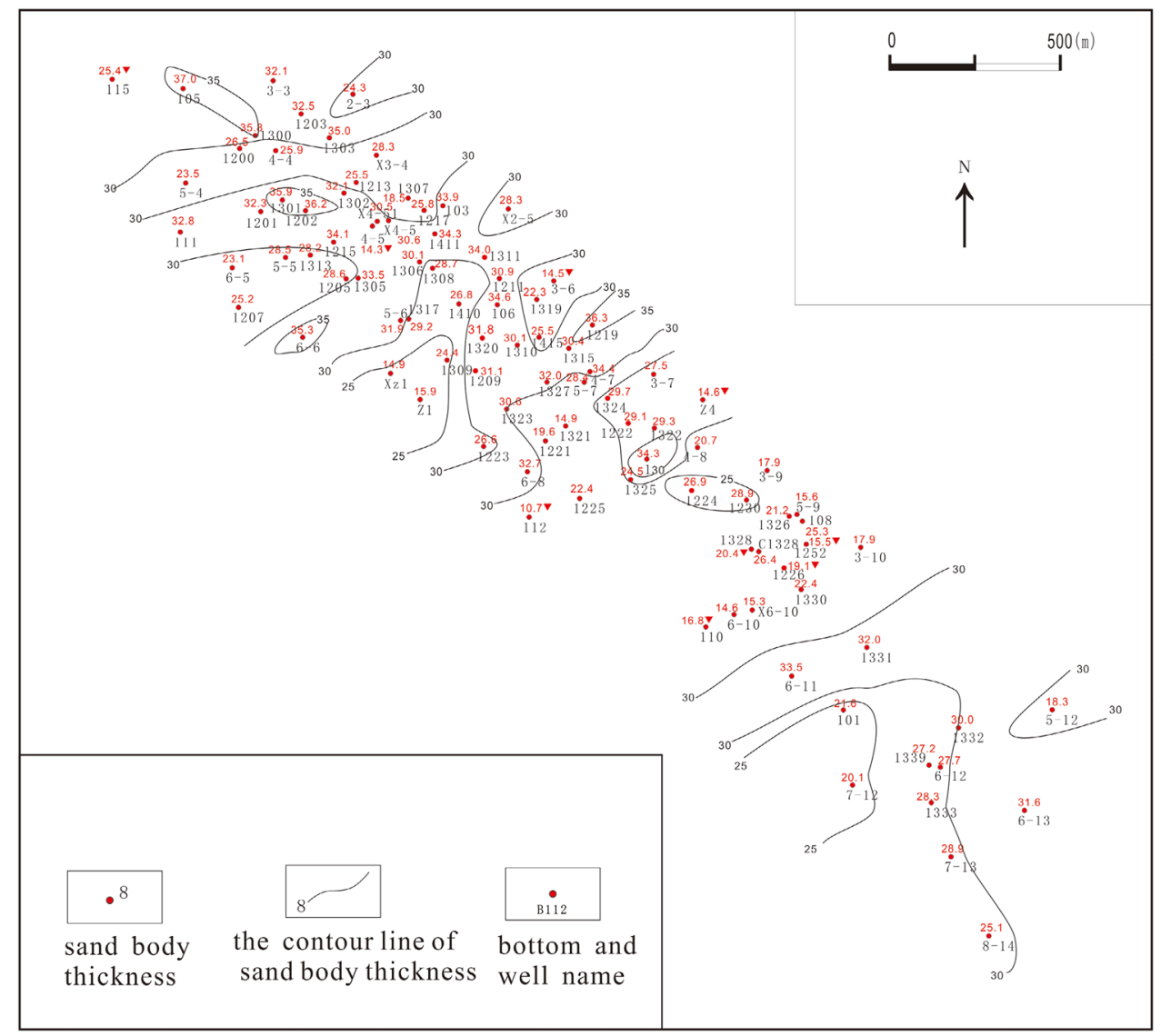

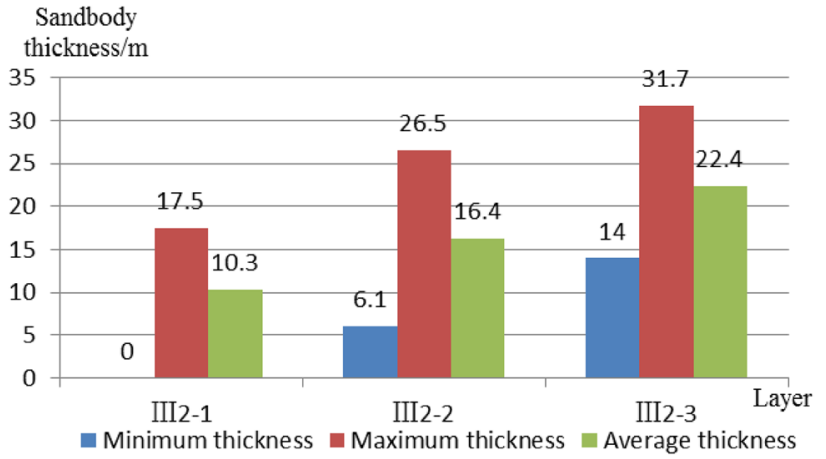

Fig. 9 Sandbody thickness of the different layer in Baobei District, Baolang oilfield

and flood period is almost equal, the quicker deposition rate of sand bodies rendered the thickness of sandstone is larger than that of mudstone.

In the prodelta, sand sheet occurred with the influence of the wave action. However, the study area was controlled by the river, thus few sand sheets existed.

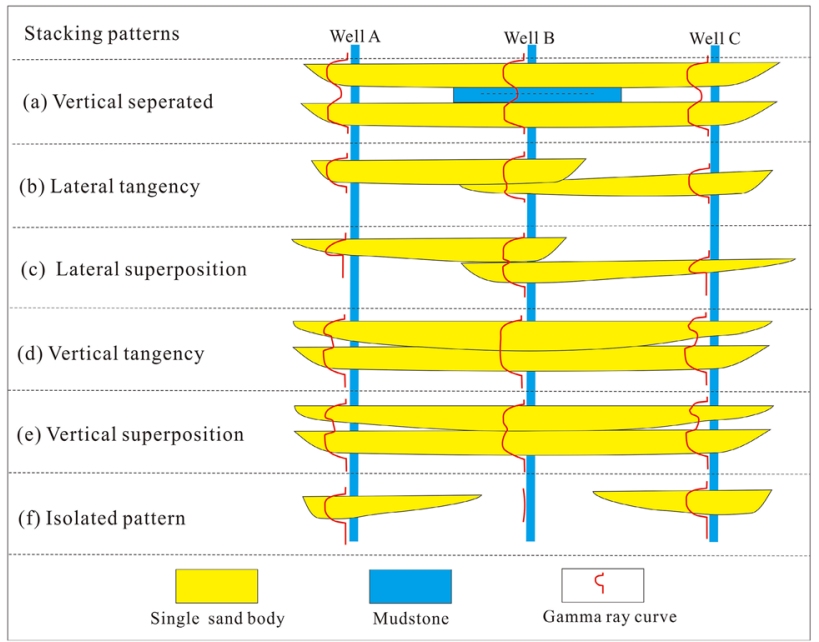

Fig. 10 Sandbodies stacking patterns

\section{Conclusions}

The study area deposits under the gentle slope depositional background. The characteristics of short distance to sediment source can be ascertained according to the low 

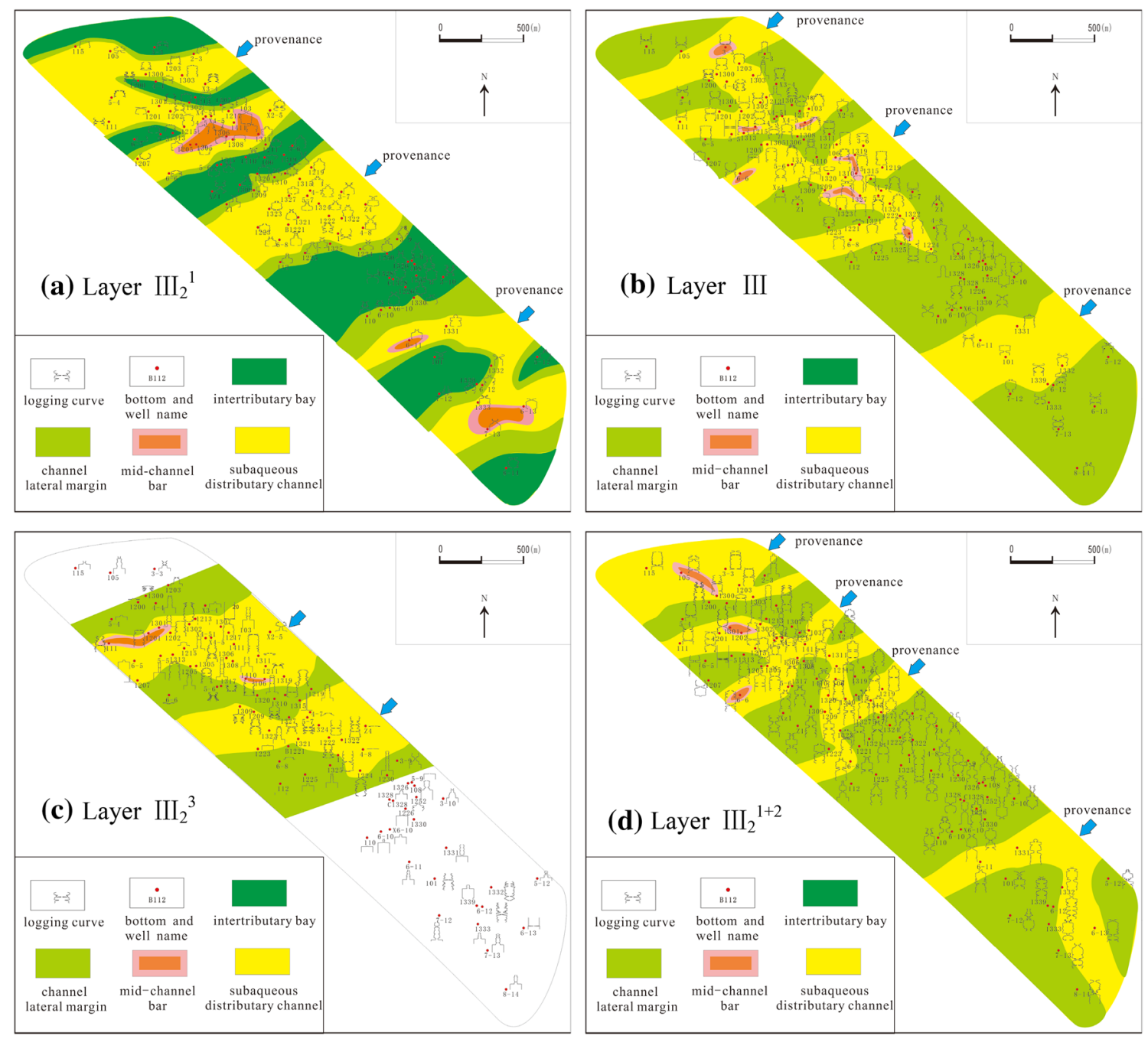

Fig. 11 Planar map of sedimentary petrofacies of III oil-bearing interval of Sanggonghe Formation in Baobei District, Baolang oilfield

Table 2 River feature of III oil-bearing interval of Sanggonghe Formation in Baobei District, Yanqi Basin

\begin{tabular}{llllll}
\hline Layer & $\begin{array}{l}\text { River } \\
\text { number }\end{array}$ & $\begin{array}{l}\text { Tributary } \\
\text { number }\end{array}$ & $\begin{array}{l}\text { Maximum } \\
\text { width }\end{array}$ & $\begin{array}{l}\text { Minimum } \\
\text { width }\end{array}$ & $\begin{array}{l}\text { Mid- } \\
\text { channel } \\
\text { bar }\end{array}$ \\
\hline $\mathrm{III}_{2}{ }^{1}$ & 3 & 5 & 400 & 80 & 3 \\
& & & 550 & 350 & \\
& & & 400 & 200 & \\
$\mathrm{III}_{2}{ }^{2}$ & 3 & 5 & 200 & 40 & 7 \\
& & & 360 & 40 & \\
& & & 400 & 200 & \\
$\mathrm{III}_{2}{ }^{3}$ & 2 & 2 & 600 & 200 & 2 \\
& & & 520 & 130 & \\
$\mathrm{III}_{2}{ }^{1+2}$ & 3 & 6 & - & 60 & 3 \\
& & & 200 & 70 & \\
& & & 400 & 150 & \\
\hline
\end{tabular}

compositional maturity, the low textural maturity and the figure $\mathrm{C}-\mathrm{M}$ of sandbody. In addition, according to figure C-M of sandbody, continuous distribution and overlapping relationship of the sandbody, and the logging curve which is dominated by box-shaped curve with a minority of bell-shaped curve, it can be confirmed that the study area develops braided river delta. The characteristics of fossil demonstrate the humid climate and the shallow water in the study area. Therefore, the study area develops shortdistance gentle slope shallow-water braided river delta.

Based on the core data and wire-line log data, eleven electrofacies are identified, including the funnel-shaped, box-shaped, bell-shaped, serrated thick logging curve and near-linear thin logging curve and so on. Moreover, four horizontal sedimentary petrofacies, including subaqueous distributary channel, mid-channel bar, channel lateral margin, and interdistributary bay, and four longitudinal sandbody types, including large, medium, small channel 


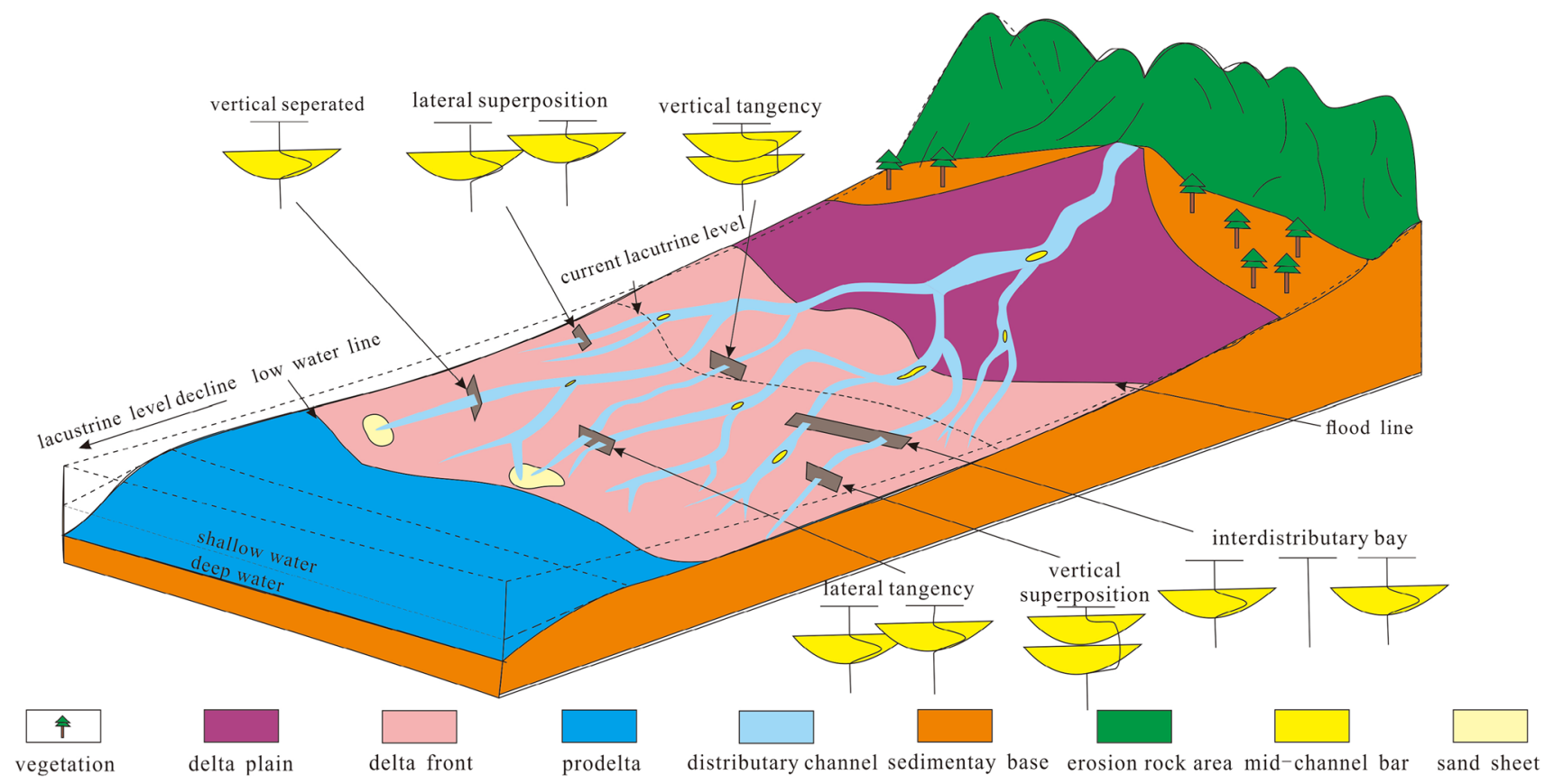

Fig. 12 Sedimentary model of III oil-bearing interval of Sanggonghe Formation in Baobei District, Baolang oilfield

sand bodies and thin sand sheet, are also recognized, respectively.

Given the condition of sedimentary background and characteristics of Sangonghe Formation in Baobei District, Baolang oilfield, synthesis effects of climate and gentle slope control the fluctuation of the lake level. Furthermore, the distribution of the facies belt, the position of the river and the distribution of the sand body are determined by the fluctuation of the lake level. The sedimentary model can be concluded as "gentle slope, strong flow, frequent fluctuation of lake level, thick and wide sand body".

Acknowledgements This work was supported by the National Science and Technology Major Project of China (No. 2017ZX05030-002), and we also gratefully acknowledge the funding support of this project from Henan oilfield company of Sinopec (No. 31350063-16-ZC0607-0006).

Open Access This article is distributed under the terms of the Creative Commons Attribution 4.0 International License (http://creativeco mmons.org/licenses/by/4.0/), which permits unrestricted use, distribution, and reproduction in any medium, provided you give appropriate credit to the original author(s) and the source, provide a link to the Creative Commons license, and indicate if changes were made.

\section{References}

Bridge JS, Tye RS (2000) Interpreting the dimentions of ancient fluvial channel bars, channels, and channel belts from Wireline-Logs and Cores. Aapg Bull 84(8):1205-1228
Chen JJ (2003) Discussion on the original appearance of the Mesozoic Yanqi basin and its later evolution and transformation. Northwest University, Xian

Chen BT, Yu XH, Pan SX, Tan CP, Li SL, Zhang YP (2013) Sedimentary characteristics and sedimentogenic-based sandbodies correlation methods of Meandering River in Toutunhe Formation, Southern Margin of Junggar Basin. Nat Gas Geosci 24(6):1132-1139

Donaldson AC (1974) Pennsylvanian sedimentation of Central Appalachians. Geol Soc Am Spec Pap 148:47-78

Du Q, Wang L, Ren J, Liu B (2012) Recognition of structural features at Baobei block, the Baolang oil field in the Yanqi Basin. Sci Technol Eng 12(17):4128-4133

Fielding CR, Trueman JD, Alexander J (2006) Holocene depositional history of the Burdekin River Delta of Northeastern Australia: a model for a low-accommodation, Highstand Delta. J Sediment Res 76(3-4):411-428

Fisk HN (1954) Sedimentary framework of the modern Mississippi delta. J Sediment Petrol 24(2):76-99

Gani MR, Bhattacharya JP (2007) Basic building blocks and process variability of a Cretaceous Delta: internal facies architecture reveals a more dynamic interaction of river, wave, and tidal processes than is indicated by external shape. J Sediment Res 77(4):284-302

Gong SL (1986) Deposition and coal accumulation environment of late early Permian shallow water delta in Yu County, Henan. Coal Geol Explor 6:4-11

Guo W, Li XG, Liu SJ, Du YQ, Yan XM (2012) Seismic facies and sedimentary facies of the lower segment of Sangonghe Formation in Bohu Depression, Yanqi Basin. Lithol Reserv 22(2):11-15

Han XD, Lou ZH, Yao YM, Yang WD, Cai XY (2000) Analysis of the sedimentary dynamic process of the shallow-water lake delta in the Songliao Basin, Northest China. Acta Mineral Sin 20(3):305-313

He YZ, Chen HD, Zhang JQ (2001) Discussion on sedimention mechanism of two Kind of deltas from Permian-carboniferous of central Ordos Basin. Oil Gas Geol 22(1):68-71 
Howell JA, Skorstad A, Macdonald A, Alex S (2008) Sedimentological parameterization of shallow-marine reservoirs. Pet Geosci 14(1):17-34

Hu B, Qi LJ, Zhang H, Feng QD, Fang JX (2006) Studying structural evolution of the Yanqi Basin with balance-section technique. J Southwest Pet Inst 28(4):17-21

Leckie DA, Wallace-Dudley KE, Vanbeselaere NA, James DP (2004) Sedimentation in a low-accommodation setting: non-marine (Cretaceous) Mannville and marine (Jurassic) Ellis Groups, Manyberries Field, southeastern Alberta. Aapg Bull 88(10):1391-1418

Lee K, Mcmechan GA, Gani MR, Bhattacharya JP, Zeng X, Howell CD (2015) 3-D Architecture and sequence stratigraphic evolution of a forced regressive top-truncated mixed-influenced delta, cretaceous wall creek sandstone, Wyoming, USA. J Sediment Res 77(4):303-323

Lemons DR, Chan MA (1999) Faciès architecture and sequence stratigraphy of fine-grained lacustrine deltas along the eastern margin of late pleistocene lake bonneville, Northern Utah and Southern Idaho. Aapg Bull 83(4):635-665

Li ZH, Huang WH (2017) Lithofacies characteristics and sedimentary model of braided delta: a case study of $\mathrm{He} 8$ member in the southern Sulige, Ordos Basin. Lithol Reserv 29(1):43-50

Li ZX, Wei JC, Li SC (1995) The depositional system of fluvialcontrolled shallow-water delta and coal-accumulation analysis in western Shandong. Coal Geol Explor 2:7-12

Liu AL, Shen F, Zhu XM, Liao JJ, Zhang XQ, Meng H (2015) Progress of shallow-water delta research and a case study of continental lake basin. Oil Gas Geol 36(4):596-604

Lou ZH, Cai XY (1999) Controls of the topography, climate and lake level fluctuation on the depositional environment of a shallowwater delta. Acta Geol Sin 73(1):83-92

Miall AD (2006) The geology of fluvial deposits: sedimentary facies, basin analysis, and petroleum geology. Springer, Berlin, pp 66-85

Overeem I, Kroonenberg SB, Veldkamp A, Groenesteijn K, Rusakov GV, Svitoch AA (2003) Small-scale stratigraphy in a large ramp delta: recent and Holocene sedimentation in the Volga delta, Caspian Sea. Sed Geol 159(3):133-157

Plint AG (2000) Sequence stratigraphy and paleogeography of a Cenomanian deltaic complex: the Dunvegan and lower Kaskapau formations in subsurface and outcrop, Alberta and British Columbia, Canada. Bull Can Pet Geol 48(1):43-79

Postma G (1990) An analysis of the variation in delta architecture. Terra Nova 2(2):124-130

Qiu RL, Chen WL, Lin SQ, Du YB, Qu YL (2001) Mesozoic sequence stratigraphy and depositional system in Yanqi basin. Earth Sci 26(6):615-620
Reading HG (2013) Sedimentary environments: processes, facies, and stratigraphy. Encycl Geol 688(5703):580-587

Sun J, Xue JJ, Wu HS, Wu AC, Song MX, Jia KF (2016) Distal finegrain shallow-water delta sedimentary characteristics and evolution: a case from Badaowan Formation in the Central Junggar Basin. Acta Sedimentol Sin 34(1):129-136

Wang JH, Yao GQ, Yuan CP, Liu B, Huang Z (2001) Macroscopic characteristic of braided distributary channel sandbody reservoirs at Baobei Block, the Baolang Oil Field in the Yanqi Basin. Geoscience 15(4):431-437

Yang BY (2004) Tectonic evolution and petroleum accumulation in Mesozoic and Cenozoic Yanqi Basin. Northwest University, Xian

Zelilidis DJW, Kontopoulos N (2002) Sedimentation and basin evolution of the Oligocene-Miocene Mesohellenic basin, Greece. Aapg Bull 86(86):161-182

Zeng H, Zhao X, Zhu X, Jin F, Dong Y, Wang Y, Mao Z, Zheng R (2015) Seismic sedimentology characteristics of sub-clinoformal shallow-water meandering river delta: a case from the Suning area of Raoyang sag in Jizhong depression, Bohai Bay Basin, NE China. Petrol Explor Dev 42(5):621-632

Zhao CL, Zhu XM (2001) Sedimentary petrology. Petroleum Industry Press, Beijing, pp 1-50

Zheng JM, Ming P (1989) Study on diagenesis of clastic reservoir. China University of Geoscience Press, Wuhan, p 49

Zhu WL, Li JP, Zhou XH, Guo YH (2008a) Neogene shallow water deltaic system and large hydrocarbon accumulation in Bohai Bay, China. Acta Sedimentol Sin 26(4):575-582

Zhu XM, Zhang YN, Yang JS, Li DJ, Zhang NF (2008b) Sedimentary characteristics of the shallow Jurassic braided river delta, the Junggar Basin. Oil Gas Geol 29(2):244-251

Zhu XM, Liu Y, Fang Q, Li Y, Liu YY, Wang R, Song J, Liu SQ, Cao HT, Liu XN (2012) Formation and sedimentary model of shallow delta in large-scale lake. Example from Cretaceous QuanTou Formation in Sanzhao Sag, Songliao Basin. Earth Sci Front 19(1):89-99

Zou CN, Zhao WZ, Zhang XY, Luo P, Wang L, Liu LH, Xue SH, Yuang XJ, Zhu RK, Tao SZ (2008) Formation and distribution of shallow-water deltas and central-basin sandbodies in large open depression lake dasins. Acta Geol Sin 82(6):813-825

Publisher's Note Springer Nature remains neutral with regard to jurisdictional claims in published maps and institutional affiliations. 